\title{
Oxo-Bridged (Haloarylimido)[tris(3,5-dimethylpyrazolyl)borato]- molybdenum(V) Complexes: Crystal Structures of Geometric Isomers of $\left[\operatorname{MoTp}^{*}(\mathrm{O}) \mathrm{Cl}\right](\mu-\mathrm{O})\left[\mathrm{MoTp} *(\mathrm{Cl})\left(\equiv \mathrm{NC}_{6} \mathrm{H}_{4} \mathrm{Br}\right)\right]$
}

\author{
Isil Topaloglu-Sozuer ${ }^{\mathrm{a}}$, Seckiner Dulger Irdem ${ }^{\mathrm{a}}$, John J. Jeffery ${ }^{\mathrm{b}}$, Hayrullah Hamidov ${ }^{\mathrm{b}}$, \\ and Ozan Sanlı Senturk ${ }^{\mathrm{c}}$ \\ ${ }^{a}$ Department of Chemistry, Faculty of Science, Izmir Institute of Technology, \\ Gulbahce Kampusu, Urla-35430, Izmir, Turkey \\ b School of Chemistry, University of Bristol, Cantock's Close, Bristol BS8 1TS, United Kingdom \\ c Steacie Institute for Molecular Sciences, National Research Council of Canada, 100 Sussex Drive, \\ Ottawa, Ontario, Canada, K1A 0R6
}

Reprint requests to Dr. I. Topaloglu-Sozuer. Fax: + 90-232-7507509.

E-mail: Isiltopaloglu@iyte.edu.tr

Z. Naturforsch. 60b, 15 - 21 (2005); received July 7, 2004

The reaction between $\left[\mathrm{MoTp}^{*}(\mathrm{O}) \mathrm{Cl}_{2}\right],\left[\mathrm{Tp}^{*}=\right.$ hydrotris(3,5-dimetylpyrazol-1-yl)borate $]$ and 4-bromoaniline in refluxing toluene gave geometric isomers of $\left[\mathrm{MoTp}^{*}(\mathrm{O}) \mathrm{Cl}\right](\mu-\mathrm{O})\left[\mathrm{MoTp}^{*}(\mathrm{Cl})\right.$ $\left.\left(\equiv \mathrm{NC}_{6} \mathrm{H}_{4} \mathrm{Br}\right)\right](\mathbf{1 a}$, cis; $\mathbf{1 b}$, trans $)$, but a similar reaction between $\left[\mathrm{MoTp}^{*}(\mathrm{O}) \mathrm{Cl}_{2}\right]$ and 4-chloroaniline yielded only one product, $\left[\mathrm{MoTp}^{*}(\mathrm{O}) \mathrm{Cl}\right](\mu-\mathrm{O})\left[\mathrm{MoTp} *(\mathrm{Cl})\left(\equiv \mathrm{NC}_{6} \mathrm{H}_{4} \mathrm{Cl}\right)\right](2)$ as a red crystalline solid. The new compounds were characterized by microanalytical data, mass, IR and ${ }^{1} \mathrm{H}$ NMR spectroscopy. The X-ray structure analysis of $\mathbf{1 a}$ and $\mathbf{1 b}$ revealed that the complexes are geometric isomers, the two chloro ligands being cis in 1a and trans in 1b. Both compounds have Mo-O-Mo linkages and nearly linear arylimido moieties.

Key words: Imido Complexes, Molybdenum Complexes, Oxo Bridged Mo(V) Complexes, Oxo Complexes, (Pyrazol)borato Complexes

\section{Introduction}

Oxo and imido ligands form commonly multiple bonds when attached to transition metal centers. There has been significant interest in the chemistry of the corresponding complexes. Of particular importance are the high-valent organo-imido and -oxo molybdenum derivatives which have been widely studied. Both the imido and oxo groups lead to stabilization of high formal oxidation states. A large number of imido compounds are known for the majority of the transition metals in various oxidation states, although high-valent centres in which the metal has a $d^{2}-d^{2}$ electronic configuration are particularly stable [1]. For the design of $\pi$-conjugated systems this type of ligation is desirable because strong interactions occur between the metal $d$ orbitals and the $p$ orbitals on nitrogen. Changing the electronic and steric characteristics of the organic group bonded to nitrogen allows the modification of the properties of the resulting metal complexes [2].
Tris(pyrazolborate) is a facially co-ordinating ligand similar to $6 \mathrm{e}^{-}$donors such as the $\mathrm{Cp}^{*}$ (pentamethylcyclopentadienyl) ligand. The sterically encumbering nature of the $\mathrm{Tp}^{*}$ ligand compared with $\mathrm{Cp}^{*}$ is widely known and exploited in the high activity of catalyst systems [3,4]. A number of transition metal imido species containing hydridotris(pyrazolborate) type ligands [5-18] and a number of systems involving $\mu$ ligation in the presence of terminal imido groups have previously been reported [19-26]. The chemistry of compounds having both arylimido and $\mu$-oxo groups in the presence of a tris(pyrazolyl)borate co-ligand has not been explored widely.

Here, we report the preparation and spectroscopic characterization of three new binuclear $\mathrm{Mo}(\mathrm{V})$ complexes, $\left[\operatorname{MoTp}{ }^{*}(\mathrm{O}) \mathrm{Cl}\right](\mu-\mathrm{O})\left[\mathrm{MoTp}^{*}(\mathrm{Cl})\right.$ $\left.\left(\equiv \mathrm{NC}_{6} \mathrm{H}_{4} \mathrm{Br}\right)\right](\mathbf{1 a}$, cis; $\mathbf{1 b}$, trans $)$ and $\left[\mathrm{MoTp}^{*}(\mathrm{O}) \mathrm{Cl}\right]-$ $(\mu-\mathrm{O})\left[\mathrm{MoTp}^{*}(\mathrm{Cl})\left(\equiv \mathrm{NC}_{6} \mathrm{H}_{4} \mathrm{Cl}\right)\right](2)$. The structures of the complexes $\mathbf{1 a}$ and $\mathbf{1 b}$ were determined by X-ray diffraction using single crystals. 


\section{Results and Discussion}

Synthetic aspects

Reaction of $\left[\mathrm{MoTp}^{*}(\mathrm{O}) \mathrm{Cl}_{2}\right]$ with 4-bromoaniline in the presence of triethylamine in toluene under reflux afforded a pair of geometric isomers $\left[\operatorname{MoTp}^{*}(\mathrm{O}) \mathrm{Cl}\right](\mu-\mathrm{O})\left[\mathrm{MoTp}^{*}(\mathrm{Cl})\left(\equiv \mathrm{NC}_{6} \mathrm{H}_{4} \mathrm{Br}\right)\right] \quad(\mathbf{1 a}$, cis; 1b, trans) in moderate yields. Similarly, the reaction of $\left[\mathrm{MoTp}^{*}(\mathrm{O}) \mathrm{Cl}_{2}\right]$ with 4-chloroaniline produced the complex $\left[\operatorname{MoTp}^{*}(\mathrm{O}) \mathrm{Cl}\right](\mu-\mathrm{O})\left[\mathrm{MoTp}^{*}(\mathrm{Cl})\right.$ $\left.\left(\equiv \mathrm{NC}_{6} \mathrm{H}_{4} \mathrm{Cl}\right)\right]$ (2). The compounds are soluble in chlorinated solvents and stable in air. They can easily be separated from the reaction mixture by crystallisation from a dichloromethane/hexane mixture (1:4). Crystals of $\mathbf{1 a}$ and $\mathbf{1 b}$ suitable for X-ray analysis were obtained by slow evaporation of their saturated dichloromethane/hexane solutions at room temperature.

There are a number of synthetic methods known for introducing imido functionality into coordination compounds. In our work the preparation of the compounds 1a, $\mathbf{1 b}$ and $\mathbf{2}$ was accomplished by double deprotonation of the $p$-substituted haloanilines. This is a well-known [1,2] synthetic methodology for the preparation of organoimido complexes of $\mathrm{Mo}(\mathrm{V})$ and $\mathrm{Mo}(\mathrm{VI})$ in which organic compounds are employed as the imido transfer reagent. Despite the steric barrier provided by the 3-methyl groups of the Tp* ligand, the formation of the Mo-O-Mo linkage in $\mathbf{1 a}, \mathbf{1 b}$ and $\mathbf{2}$ is interesting. It could be suggested that compounds $\mathbf{1 a}$, $\mathbf{1 b}$ and $\mathbf{2}$ were formed by treating [ $\mathrm{MoTp}^{*} \mathrm{OCl}_{2}$ ] with $p$-substituted haloanilines, each of which undergoes double deprotonation to yield the mononuclear species [MoTp* $\left.\mathrm{OCl}\left(\mathrm{H}_{2} \mathrm{NC}_{6} \mathrm{H}_{4} \mathrm{X}\right)\right],\left[\mathrm{MoTp} * \mathrm{OCl}\left(\mathrm{HNC}_{6} \mathrm{H}_{4} \mathrm{X}\right)\right]$ and $\left[\mathrm{MoTp}{ }^{*} \mathrm{OCl}\left(\equiv \mathrm{NC}_{6} \mathrm{H}_{4} \mathrm{X}\right)\right] \quad(\mathrm{X}=\mathrm{Cl}$ or $\mathrm{Br})$ as a sequence of intermediates. The mononuclear imido species, $\left[\mathrm{MoTp}{ }^{*} \mathrm{OCl}\left(\equiv \mathrm{NC}_{6} \mathrm{H}_{4} \mathrm{X}\right)\right]$, further reacts with unreacted starting material to form the oxo-bridged dimetallic (haloaryl) imido molybdenum(V) compounds $\left[\mathrm{MoTp}^{*}(\mathrm{O}) \mathrm{Cl}\right](\mu-\mathrm{O})-$ $\left[\operatorname{MoTp}^{*}(\mathrm{Cl})\left(\equiv \mathrm{NC}_{6} \mathrm{H}_{4} \mathrm{Br}\right)\right](\mathbf{1 a}$, cis; $\mathbf{1 b}$, trans $)$ and $\left[\mathrm{MoTp}^{*}(\mathrm{O}) \mathrm{Cl}\right](\mu-\mathrm{O})\left[\mathrm{MoTp}^{*}(\mathrm{Cl})\left(\equiv \mathrm{NC}_{6} \mathrm{H}_{4} \mathrm{Cl}\right)\right]$ according to the following reactions.

$$
\begin{aligned}
{\left[\mathrm{MoTp}^{*} \mathrm{OCl}_{2}\right]+\mathrm{H}_{2} \mathrm{NC}_{6} \mathrm{H}_{4} \mathrm{X} \underset{\text { toluene }}{\longrightarrow} } & {\left[\mathrm{Et}_{3} \mathrm{~N}\right.} \\
& {\left[\mathrm{Cl}_{2}(\mathrm{O}) \mathrm{Tp}^{*} \mathrm{Mo}\left(\mathrm{HNC}_{6} \mathrm{H}_{4} \mathrm{X}\right)\right] \stackrel{\left[\mathrm{MoTp}^{*} \mathrm{OCl}_{2}\right]}{\longrightarrow} } \\
& {\left[\mathrm{Cl}(\mathrm{O}) \mathrm{Tp}^{*} \mathrm{Mo}\left(\equiv \mathrm{NC}_{6} \mathrm{H}_{4} \mathrm{X}\right)\right] \stackrel{[}{\longrightarrow} } \\
& {\left[\mathrm{Cl}(\mathrm{O}) \mathrm{Tp}^{*} \mathrm{Mo}(\mu-\mathrm{O}) \mathrm{MoTp}^{*} \mathrm{Cl}\left(\equiv \mathrm{NC}_{6} \mathrm{H}_{4} \mathrm{X}\right)\right] } \\
(\mathrm{X}= & \mathrm{Br}, \mathbf{1 a}, \text { cis } ; \mathbf{1 b}, \text { trans } ; \mathrm{Cl}, \mathbf{2})
\end{aligned}
$$

In the reaction of $\left[\mathrm{MoTp}^{*} \mathrm{OCl}_{2}\right]$ with 4-bromoaniline, both cis and trans isomers were obtained. No fluxional behaviour was observed in solution related to 1a and 1b. Only one compound was generated in the reaction of $\left[\mathrm{MoTp}^{*} \mathrm{OCl}_{2}\right]$ with 4-chloroaniline though there were some unidentified minor bands in the column chromatography.

\section{Spectroscopic studies}

Molecular ion peaks in the mass spectra are in accord with the X-ray structures for $\mathbf{1 a}$ and $\mathbf{1 b}$. The molecular ion peak for compund $\mathbf{2}$ is also consistent with the proposed structure. The ${ }^{1} \mathrm{H}$ NMR spectra of the complexes are in accord with their formulation. The signals attributable to $\mathrm{Tp}^{*}$ appear as two groups of singlets in the regions $\delta 5.24-6.20 \mathrm{ppm}$, assigned to the pyrazolyl $\mathrm{C}-\mathrm{H}$ protons, and $\delta 2.24-3.41 \mathrm{ppm}$ assigned to the methyl protons. Owing to the low symmetry of the complexes all three pyrazolyl C-H protons and all six methyl groups of the $\mathrm{Tp}^{*}$ ligand are expected to be nonequivalent in the NMR spectra. In the spectra of $\mathbf{1 b}$ and $\mathbf{2}$, six signals due to the pyrazolyl C-H protons were indeed observed for two nonequivalent $\mathrm{Tp}^{*}$ ligands, whereas for $\mathbf{1 a}$, three signals appear in the intensity ratio $1: 1: 1$. The observation of three signals instead of six, could be attributed to coincidental overlap of resonances of two nonequivalent Tp* ligands. The $\mathrm{C}_{6} \mathrm{H}_{4}$ ring protons of the compounds $\mathbf{1 b}$ and $\mathbf{2}$ are split into two sets of two whereas in 1a they are all equivalent and only a single signal is observed.

The NH protons generally appear as a sharp singlet in the range $\delta 11-13 \mathrm{ppm}$ [1]. The ${ }^{1} \mathrm{H}$ NMR spectra of 1a, $\mathbf{1 b}$ and $\mathbf{2}$ did not display any signals in this region which led us to consider the existence of either $\mathrm{Mo}=\mathrm{N}$ or $\mathrm{Mo} \equiv \mathrm{N}$ linkages.

Further evidence that supports the existence of either $\mathrm{Mo}=\mathrm{N}$ or $\mathrm{Mo} \equiv \mathrm{N}$ linkages was provided by the IR spectra of $\mathbf{1 a}, \mathbf{1 b}$ and $\mathbf{2}$ because the vibrations at ca. 3370 and $3450 \mathrm{~cm}^{-1}$ for the symmetric and asymmetric stretching modes of the $\mathrm{NH}_{2}$ groups of the free ligands have completely disappeared. A value of $1100-1300 \mathrm{~cm}^{-1}$ for $v_{(\mathrm{Mo} \equiv \mathrm{N})}$ has been suggested by Dehnicke [27], and McCleverty et al. [11] reported values in the range $1200-1250 \mathrm{~cm}^{-1}$ for $\mathrm{Mo}=\mathrm{N}$ linkages in the compounds [MoTp* $(\mathrm{O}) \mathrm{Cl}(=\mathrm{NR})](\mathrm{R}=4$-tolyl, and $\left.\mathrm{C}_{6} \mathrm{H}_{4} \mathrm{NMe}_{2}-4\right)$. The IR spectra of $\mathbf{1 a}, \mathbf{1 b}$ and $\mathbf{2}$ also exhibit peaks in the $1200-1300 \mathrm{~cm}^{-1}$ range which may be ascribed to $v_{(\mathrm{Mo} \equiv \mathrm{N})}$. 


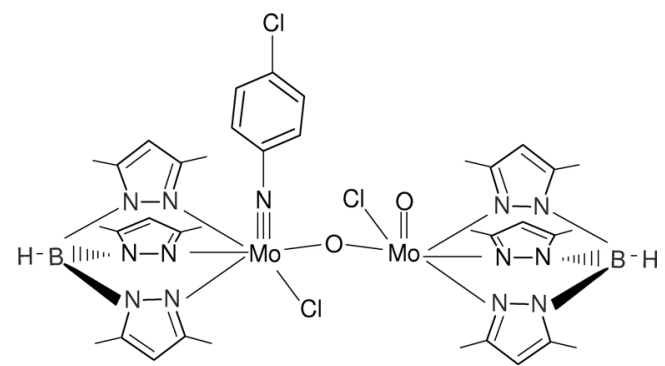

Fig. 1. The proposed structure of compound 2.

The presence of $\mathrm{Tp}^{*}$ was confirmed by the observation of bands attributable to $v_{(\mathrm{BH})}$ ( $c a$. $\left.2500 \mathrm{~cm}^{-1}\right)$. The $\mathrm{Mo}=\mathrm{O}$ stretching vibrations occur at ca. $950-960 \mathrm{~cm}^{-1}$ which is characteristic of the terminal $\mathrm{Mo}=\mathrm{O}$ unit in $\mathrm{Mo}(\mathrm{V})$ complexes. $\left[\mathrm{MoTp}^{*}(\mathrm{O}) \mathrm{Cl}\right]_{2}(\mu-\mathrm{O})$ exhibits two $v_{(\mathrm{Mo}=\mathrm{O})}$ at 960 and $859 \mathrm{~cm}^{-1}$ [28]. Both $\left[\mathrm{MoTp}(\mathrm{O}) \mathrm{Cl}_{2}\right](\mu-\mathrm{O})\left(\right.$ cis, $\mathrm{C}_{2}$ isomer) and $\left.[\mathrm{MoTp} \mathrm{O}) \mathrm{Cl}_{2}\right](\mu-\mathrm{O})$, (trans, $\mathrm{C}_{\mathrm{i}}$ isomer) exhibit a peak at $958 \mathrm{~cm}^{-1}$ for the terminal oxo groups [29] as well as peaks at 784 and $456 \mathrm{~cm}^{-1}$. The last two vibrations were assigned to the asymmetric stretch and the deformation mode of the linear oxobridged unit, respectively [30]. For $\left[\mathrm{MoTp}^{*}(\mathrm{O}) \mathrm{Cl}\right]_{2}(\mu-$ $\mathrm{O})$, a medium intensity band at $753 \mathrm{~cm}^{-1}$ was also assigned to the asymmetric stretching mode of a bridging Mo-O-Mo unit [30]. Hence, the peaks observed for the new compounds $\mathbf{1 a}, \mathbf{1 b}$ and 2 at $c a$. $757-787 \mathrm{~cm}^{-1}$ can be assigned accordingly.

The IR spectra of $\mathbf{1 a}$ and $\mathbf{1 b}$ are almost identical, and the IR spectrum of $\mathbf{2}$ resembles that of either compound. Thus the determination of the structure of $\mathbf{2}$ cannot be made on the basis of IR spectra alone. On the other hand, the ${ }^{1} \mathrm{H}$ NMR data of 2 closely match that of $\mathbf{1 b}$ in which two chlorine atoms are trans to each other. Therefore, it would seem plausible to assume that compound $\mathbf{2}$ has the same geometry as $\mathbf{1 b}$ (Fig. 1).

\section{Crystal structure}

An ORTEP view of the molecular structures of 1a and $\mathbf{1 b}$ along with the atom numbering schemes are shown in Figs. 1 and 2, respectively. Selected bond distances and bond angles are listed in Table 1. Both complexes have two nonequivalent $\mathrm{MoTp}{ }^{*} \mathrm{Cl}$ units connected by a single oxo bridge. There are two pseudooctahedral metal centers with three nitrogen atoms of each Tp* ligand occupying one face of the octahedron. One Mo atom is coordinated by an arylimido, a fa-
Table 1. Selected bond lengths $(\AA)$ and bond angles $\left(^{\circ}\right)$ for $\mathbf{1 a}$ and $\mathbf{1 b}$.

\begin{tabular}{lcll}
\hline \multicolumn{3}{c}{ 1a. $2 \mathrm{CH}_{2} \mathrm{Cl}_{2}$} & \multicolumn{2}{c}{ 1b. $2 \mathrm{CH}_{2} \mathrm{Cl}_{2}$} \\
\hline Bond lengths & & & \\
$\mathrm{Mo}(1)-\mathrm{N}(1)$ & $1.7477(19)$ & $\mathrm{Mo}(1)-\mathrm{N}(1)$ & $1.727(5)$ \\
$\mathrm{N}(1)-\mathrm{C}(1)$ & $1.390(3)$ & $\mathrm{N}(1)-\mathrm{C}(1)$ & $1.391(8)$ \\
$\mathrm{Br}(4)-\mathrm{C}(4)$ & $1.897(3)$ & $\mathrm{Br}(4)-\mathrm{C}(4)$ & $1.883(7)$ \\
$\mathrm{Mo}(1)-\mathrm{O}(1)$ & $1.9088(16)$ & $\mathrm{Mo}(1)-\mathrm{O}(1)$ & $1.903(4)$ \\
$\mathrm{Mo}(1)-\mathrm{N}(31)$ & $2.2612(14)$ & $\mathrm{Mo}(1)-\mathrm{N}(31)$ & $2.174(5)$ \\
$\mathrm{Mo}(1)-\mathrm{N}(11)$ & $2.2057(19)$ & $\mathrm{Mo}(1)-\mathrm{N}(11)$ & $2.223(5)$ \\
$\mathrm{Mo}(1)-\mathrm{N}(21)$ & $2.1765(19)$ & $\mathrm{Mo}(1)-\mathrm{N}(21)$ & $2.275(5)$ \\
$\mathrm{Mo}(1)-\mathrm{Cl}(1)$ & $2.4165(6)$ & $\mathrm{Mo}(1)-\mathrm{Cl}(1)$ & $2.4191(19)$ \\
$\mathrm{Mo}(2)-\mathrm{O}(1)$ & $1.8689(16)$ & $\mathrm{Mo}(2)-\mathrm{O}(1)$ & $1.880(4)$ \\
$\mathrm{Mo}(2)-\mathrm{O}(2)$ & $1.6750(17)$ & $\mathrm{Mo}(2)-\mathrm{O}(2)$ & $1.682(4)$ \\
$\mathrm{Mo}(2)-\mathrm{N}(51)$ & $2.3172(16)$ & $\mathrm{Mo}(2)-\mathrm{N}(51)$ & $2.167(5)$ \\
$\mathrm{Mo}(2)-\mathrm{N}(41)$ & $2.2272(17)$ & $\mathrm{Mo}(2)-\mathrm{N}(41)$ & $2.221(5)$ \\
$\mathrm{Mo}(2)-\mathrm{N}(61)$ & $2.1800(19)$ & $\mathrm{Mo}(2)-\mathrm{N}(61)$ & $2.350(5)$ \\
$\mathrm{Mo}(2)-\mathrm{Cl}(2)$ & $2.4071(6)$ & $\mathrm{Mo}(2)-\mathrm{Cl}(2)$ & $2.3958(18)$ \\
$\mathrm{Bond}$ angles & & & \\
$\mathrm{N}(1)-\mathrm{Mo}(1)-\mathrm{O}(1)$ & $104.81(8)$ & $\mathrm{N}(1)-\mathrm{Mo}(1)-\mathrm{O}(1)$ & $100.42(12)$ \\
$\mathrm{C}(1)-\mathrm{N}(1)-\mathrm{Mo}(1)$ & $156.19(17)$ & $\mathrm{C}(1)-\mathrm{N}(1)-\mathrm{Mo}(1)$ & $176.0(4)$ \\
$\mathrm{O}(1)-\mathrm{Mo}(1)-\mathrm{N}(31)$ & $87.32(7)$ & $\mathrm{O}(1)-\mathrm{Mo}(1)-\mathrm{N}(31)$ & $89.96(18)$ \\
$\mathrm{O}(1)-\mathrm{Mo}(1)-\mathrm{N}(11)$ & $167.59(7)$ & $\mathrm{O}(1)-\mathrm{Mo}(1)-\mathrm{N}(11)$ & $165.57(17)$ \\
$\mathrm{O}(1)-\mathrm{Mo}(1)-\mathrm{N}(21)$ & $93.58(7)$ & $\mathrm{O}(1)-\mathrm{Mo}(1)-\mathrm{N}(21)$ & $87.05(18)$ \\
$\mathrm{N}(1)-\mathrm{Mo}(1)-\mathrm{Cl}(1)$ & $101.61(6)$ & $\mathrm{N}(1)-\mathrm{Mo}(1)-\mathrm{Cl}(1)$ & $95.73(17)$ \\
$\mathrm{O}(1)-\mathrm{Mo}(1)-\mathrm{Cl}(1)$ & $92.52(5)$ & $\mathrm{O}(1)-\mathrm{Mo}(1)-\mathrm{Cl}(1)$ & $98.24(13)$ \\
$\mathrm{N}(31)-\mathrm{Mo}(1)-\mathrm{Cl}(1)$ & $88.40(5)$ & $\mathrm{N}(31)-\mathrm{Mo}(1)-\mathrm{Cl}(1)$ & $166.36(13)$ \\
$\mathrm{N}(11)-\mathrm{Mo}(1)-\mathrm{Cl}(1)$ & $87.82(5)$ & $\mathrm{N}(11)-\mathrm{Mo}(1)-\mathrm{Cl}(1)$ & $87.86(15)$ \\
$\mathrm{N}(21)-\mathrm{Mo}(1)-\mathrm{Cl}(1)$ & $168.69(5)$ & $\mathrm{N}(21)-\mathrm{Mo}(1)-\mathrm{Cl}(1)$ & $85.40(14)$ \\
$\mathrm{N}(11)-\mathrm{Mo}(1)-\mathrm{N}(31)$ & $80.29(7)$ & $\mathrm{N}(11)-\mathrm{Mo}(1)-\mathrm{N}(31)$ & $81.78(18)$ \\
$\mathrm{N}(51)-\mathrm{Mo}(2)-\mathrm{N}(61)$ & $83.45(7)$ & $\mathrm{N}(51)-\mathrm{Mo}(2)-\mathrm{N}(61)$ & $81.74(18)$ \\
$\mathrm{Mo}(2)-\mathrm{O}(1)-\mathrm{Mo}(1)$ & $175.78(9)$ & $\mathrm{Mo}(2)-\mathrm{O}(1)-\mathrm{Mo}(1)$ & $167.92(17)$ \\
$\mathrm{O}(2)-\mathrm{Mo}(2)-\mathrm{O}(1)$ & $105.33(8)$ & $\mathrm{O}(2)-\mathrm{Mo}(2)-\mathrm{O}(1)$ & $101.72(19)$ \\
$\mathrm{O}(2)-\mathrm{Mo}(2)-\mathrm{Cl}(2)$ & $97.05(6)$ & $\mathrm{O}(2)-\mathrm{Mo}(2)-\mathrm{Cl}(2)$ & $100.13(16)$ \\
$\mathrm{O}(1)-\mathrm{Mo}(2)-\mathrm{Cl}(2)$ & $94.22(5)$ & $\mathrm{O}(1)-\mathrm{Mo}(2)-\mathrm{Cl}(2)$ & $95.54(13)$ \\
\hline & & & \\
& & & \\
& & &
\end{tabular}

cial $\mathrm{Tp}^{*}$, a terminal chloro and a bridging oxo ligand whereas the second Mo atom is coordinated by a terminal oxo, a facial Tp*, a terminal chloro, and a bridging oxo ligand. The two chlorine atoms are $\mathrm{cis}$ to each other in 1a, while the X-ray structure determination of 1b revealed it to be a geometrical isomer with the two chloride ligands trans to each other.

There are two interesting features related to the crystal structures of $\mathbf{1 a}$ and $\mathbf{1 b}$. Firstly, there is an MoN-R linkage which could be considered as near-linear with $\mathrm{Mo}(1)-\mathrm{N}(1)-\mathrm{C}(1)$ bond angles of $156.19(17)^{\circ}$ in 1a and $176.0(4)^{\circ}$ in $\mathbf{1 b}$, respectively. These values are in accord with the range of $160-180^{\circ}$ for linear angles suggested by Dehnicke [27]. It was reported that near-linear angles in the range $150-180^{\circ}$ are frequently observed and can be influenced by interligand steric interactions as well as molecule packing forces $[12,31]$. For the compounds [Tp* $\left.\mathrm{Mo}(\mathrm{NAr})_{2} \mathrm{Cl}\right]$ and $\left[\mathrm{Tp}^{*} \mathrm{Mo}(\mathrm{NAr})\left(\mathrm{NBu}^{t}\right) \mathrm{Cl}\right]\left(\mathrm{Ar}=2,6-\mathrm{Pr}_{2}{ }_{2} \mathrm{C}_{6} \mathrm{H}_{3}\right)$, the Mo-N-C bond angles are reported as $173.06(16)^{\circ}$ and 


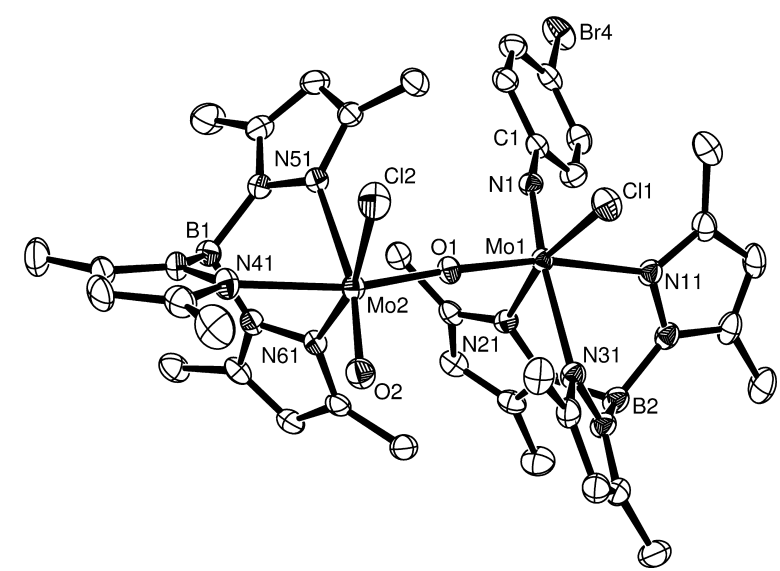

Fig. 2. ORTEP view of the molecular structure of 1a. Atoms are represented as $50 \%$ probability ellipsoids.

168.25(16) ${ }^{\circ}$, respectively [24]. Secondly, a near linear Mo-O-Mo bridge is present with a bond angle of $175.78(9)^{\circ}$ in $\mathbf{1 a}$ and of $167.92^{\circ}$ in $\mathbf{1 b}$. Mo-O-Mo bond angles for the geometric isomers of $[\mathrm{MoTp}(\mathrm{O}) \mathrm{Cl}]_{2}(\mu-$ $\mathrm{O})$ were reported as $177.32^{\circ}\left(\mathrm{cis}, \mathrm{C}_{2}\right)$ and $180.0^{\circ}$ for (trans, $\mathrm{C}_{\mathrm{i}}$ ).

$\mathrm{O}_{(\text {brid })}-\mathrm{Mo}(1)-\mathrm{O}_{(\text {ter })}$ bond angles of $105.33(8)^{\circ}$ and $101.72(19)^{\circ}$ for $\mathbf{1 a}$ and $\mathbf{1 b}$, respectively, are close to the values of $103.8(1)^{\circ}, 104.03(18)^{\circ}$ and $102.22^{\circ}$ reported for $\left[\mathrm{MoTp}^{*}(\mathrm{O}) \mathrm{Cl}\right]_{2}(\mu-\mathrm{O}),\left[\mathrm{MoTp}^{\mathrm{Pr}}(\mathrm{O}) \mathrm{Cl}\right](\mu-$ $\mathrm{O})\left[\mathrm{MoTp}^{\mathrm{Pr}}(\mathrm{O})(\mathrm{OH})\right]\left(\mathrm{Tp}^{\mathrm{Pr}}=\operatorname{hydrotris}(3\right.$-isopropylpyrazolyl)borate) $[28]$ and $\left[\mathrm{MoTp}(\mathrm{O}) \mathrm{Cl}_{2}(\mu-\mathrm{O})\left(\mathrm{C}_{2}\right.\right.$, cis), respectively [29].

The Mo-N and N-C distances fall into the ranges reported for similar compounds [32]. Mo(1)-N(1) and $\mathrm{N}(1)-\mathrm{C}(1)$ are 1.7477(19) and 1.390(3) ( $\AA$ ) for $\mathbf{1 a}$ and $1.727(5)$ and $1.391(8)$ for $\mathbf{1 b}$, respectively. The N$\mathrm{C}$ bonds are too short for a Mo-N single bond and indicate a $\mathrm{Mo}=\mathrm{N}$ or a $\mathrm{Mo} \equiv \mathrm{N}$ bond, in agreement with previously reported values [27]. The $\mathrm{Tp}^{*}$ ligand is coordinated to each molybdenum atom with Mo-N bond lenghts (Table 1) typical for this type of compounds [29].

In case of transition metals in high oxidation states, the free electron pair of a nitrogen atom participates in the M-N bond, resulting in a linear M-N-R arrangement with an $\mathrm{M} \equiv \mathrm{N}$ triple bond [27]. Considering the $\mathrm{Mo}-\mathrm{N}-\mathrm{C}$ bond angles and the electron count $\mathrm{Mo} \equiv \mathrm{N}$ linkages are also to be assumed for $\mathbf{1 a}$ and $\mathbf{1 b}$. In general, two Lewis structures have been proposed for the metal nitrogen bond in imido complexes [32].

The $\operatorname{Mo}(2)-\mathrm{O}(2), \quad \mathrm{Mo}(1)-\mathrm{Cl}(1), \quad \mathrm{Mo}(2)-\mathrm{Cl}(2)$, $\mathrm{Mo}(1)-\mathrm{O}(1)$ and $\mathrm{Mo}(2)-\mathrm{O}(1)$ distances of 1.6750(17),

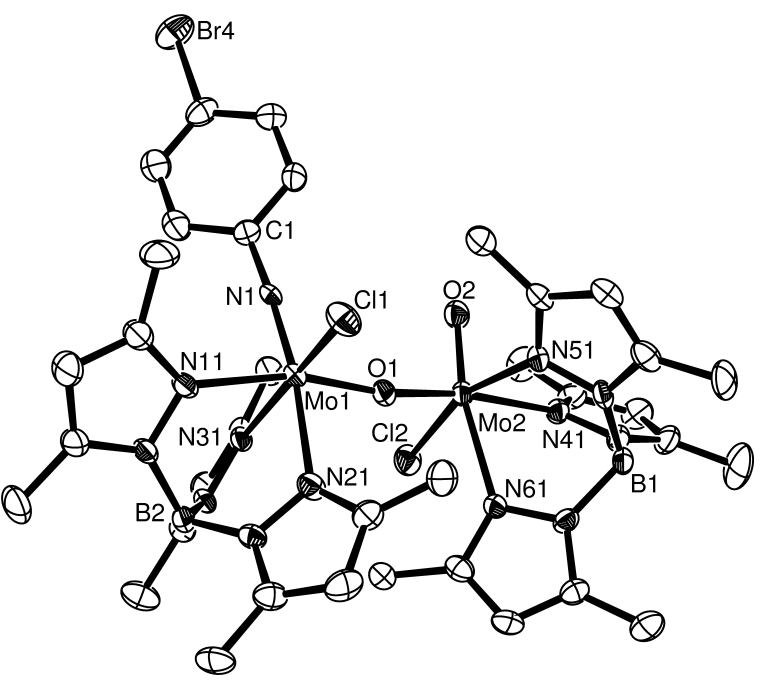

Fig. 3. ORTEP view of the molecular structure of 1b. Atoms are represented as $50 \%$ probability ellipsoids.

2.4165(6), 2.4071(6), 1.9088(16) and 1.8689(16) $\AA$ for $1 \mathrm{a}$ and $\mathrm{Mo}(1)-\mathrm{O}(1), \mathrm{Mo}(2)-\mathrm{O}(1), \mathrm{Mo}(2)-\mathrm{O}(2)$, $\mathrm{Mo}(1)-\mathrm{Cl}(1)$, and $\mathrm{Mo}(2)-\mathrm{Cl}(2)$ distances of 1.903(4), 1.880(4), 1.682(4), 2.4191(19), and 2.3958(18) $\AA$ for $\mathbf{1 b}$ are all within expected ranges $[33,34]$.

\section{Experimental Section}

All preparations and manipulations were carried out with Schlenk techniques under an oxygen-free nitrogen atmosphere. All glassware was oven-dried at $120{ }^{\circ} \mathrm{C}$. Solvents were dried by standard procedures, distilled and kept under nitrogen over $4 \AA$ molecular sieves.

The starting material $\left[\mathrm{MoTp}^{*}(\mathrm{O}) \mathrm{Cl}_{2}\right]$ was prepared according to Enamark's published method [35].

Infrared spectra were recorded on a Magna IR spectrophotometer as pressed $\mathrm{KBr}$ disks. ${ }^{1} \mathrm{H}$ NMR spectra were recorded in $\mathrm{CDCl}_{3}$ on $400 \mathrm{MHz}$ High Performance Digital f.t.-NMR at TUBITAK (Research Council of Turkey). Mass spectra analyses were performed on a Joel AX505 FAB device using $\mathrm{Xe}$ at $3 \mathrm{KV}$ as a positive ion and a matrix m-NBA (meta-nitrobenzyl alcohol). Elemental analyses were carried out using a LECO CHNS 932 instrument. The crystal structure determination was done by using a Bruker SMART CCD area-dedector diffractometer.

\section{Syntheses}

$\left[\operatorname{MoTp}^{*}(\mathrm{O}) \mathrm{Cl}\right](\mu-\mathrm{O})\left[\mathrm{MoTp}^{*}(\mathrm{Cl})\left(\equiv \mathrm{NC}_{6} \mathrm{H}_{4} \mathrm{Br}\right)\right](\mathbf{1 a}, \mathrm{cis} ; \mathbf{1 b}$, trans)

A mixture of $\left[\mathrm{MoTp}^{*}(\mathrm{O}) \mathrm{Cl}_{2}\right](0.4 \mathrm{~g}, 0.83 \mathrm{mmol})$, 4-bromoaniline $(0.28 \mathrm{~g}, 1.66 \mathrm{mmol})$ and dry $\mathrm{Et}_{3} \mathrm{~N}\left(0.6 \mathrm{~cm}^{3}\right)$ in dry toluene $\left(20 \mathrm{~cm}^{3}\right)$ was heated to reflux with stirring 


\begin{tabular}{lll}
\hline & \multicolumn{1}{c}{$\mathbf{1 a} \cdot 2 \mathrm{CH}_{2} \mathrm{Cl}_{2}$} & \multicolumn{1}{c}{$\mathbf{1 b} \cdot 2 \mathrm{CH}_{2} \mathrm{Cl}_{2}$} \\
\hline Empirical formula & $\mathrm{C}_{36} \mathrm{H}_{48} \mathrm{~B}_{2} \mathrm{Cl}_{2} \mathrm{Br} \mathrm{Mo}_{2} \mathrm{~N}_{13} \mathrm{O}_{2} .2 \mathrm{CH}_{2} \mathrm{Cl}_{2} \mathrm{C}_{36} \mathrm{H}_{48} \mathrm{~B}_{2} \mathrm{Cl}_{2} \mathrm{Br} \mathrm{Mo}_{2} \mathrm{~N}_{13} \mathrm{O}_{2} \cdot 2 \mathrm{CH}_{2} \mathrm{Cl}_{2}$ \\
Formula weight & 1229.05 & 1229.05 \\
Temperature & $1732 \mathrm{~K}$ & $1732 \mathrm{~K}$ \\
Wavelength & $0.71073 \AA$ & $0.71073 \AA$ \\
Crystal system & monoclinic & monoclinic \\
Space group & $C 2 / c$ & $P 2 / n$ \\
Unit cell dimensions & $a=41.8706(16) \AA, \alpha=90^{\circ}$ & $a=9.622(3) \AA, \alpha=90^{\circ}$ \\
& $b=12.3819(5) \AA, \beta=98.6370(10)^{\circ}$ & $b=23.426(8) \AA, \beta=99.326(7)^{\circ}$ \\
& $c=19.4469(8) \AA, \gamma=90^{\circ}$ & $c=23.703(8) \AA, \gamma=90^{\circ}$ \\
Volume & $9967.7(7) \AA^{3}$ & $5272(3) \AA^{3}$ \\
$Z$ & 8 & 4 \\
Density (calculated) & $1.638 \mathrm{mg} / \mathrm{cm}^{3}$ & $1.526 \mathrm{mg} / \mathrm{cm}^{3}$ \\
Absorption coefficient & $1.675 \mathrm{~mm}{ }^{-1}$ & $1.558 \mathrm{~mm}{ }^{-1}$ \\
$F(000)$ & 4944 & 2438 \\
Crystal size & $0.5 \times 0.5 \times 0.4 \mathrm{~mm}$ & $0.2 \times 0.2 \times 0.1 \mathrm{~mm}$ \\
$\theta$ Range for & & \\
data collection & 1.72 to $27.48^{\circ}$ & 1.94 to $27.51^{\circ}$ \\
Index ranges & $-51 \leq h \leq 54$, & $-11 \leq h \leq 12$, \\
& $-16 \leq k \leq 15$, & $-30 \leq k \leq 30$, \\
Reflections collected & 37500 & $-30 \leq l \leq 30$ \\
Refinement method & full-matrix least-squares on $\mathrm{F}^{2}$ & 39944 \\
Largest diff. & & Full-matrix least-squares on $\mathrm{F}^{2}$ \\
peak and hole & 0.957 and $-0.559 \mathrm{e}^{-3}$ & $1.687 \mathrm{and}-1.109 \mathrm{e}^{-3}$ \\
\hline & &
\end{tabular}

Table 2. Crystal data and structure refinement for $\mathbf{1 a}$ and $\mathbf{1 b}$. under $\mathrm{N}_{2}$ for $14 \mathrm{~h}$, during which time the solution became dark red-brown in colour. The mixture was cooled, filtered and evaporated to dryness. The residue was dissolved in dichloromethane and chromatographed on silica gel using $\mathrm{CH}_{2} \mathrm{Cl}_{2} / n$-hexane $(9: 1, \mathrm{v} / \mathrm{v})$ as eluant. Two dark-red fractions were collected, crystallised from $\mathrm{CH}_{2} \mathrm{Cl}_{2} / n$ hexane and identified, respectively, as $\left[\mathrm{MoTp}^{*}(\mathrm{O}) \mathrm{Cl}\right](\mu-\mathrm{O})$ $\left[\mathrm{MoTp}^{*}(\mathrm{Cl})\left(\equiv \mathrm{NC}_{6} \mathrm{H}_{4} \mathrm{Br}\right)\right](\mathbf{1 a}$, cis $)$, Yield: $30 \%$. IR(KBr) $v=2548(\mathrm{~m}, \mathrm{~B}-\mathrm{H}), 957(\mathrm{~s}, \mathrm{Mo}=\mathrm{O}), 1205(\mathrm{~s}, \mathrm{Mo} \equiv \mathrm{N})$, 757 (m, Mo-O-Mo). - ${ }^{1} \mathrm{H}$ NMR (400 $\left.\mathrm{MHz}, \mathrm{CDCl}_{3}\right)$ : $\delta=7.41\left(\mathrm{~s}, 4 \mathrm{H}, \mathrm{C}_{6} \mathrm{H}_{4} \mathrm{Br}\right), 6.04,5.95,5.68(3 \times s, 6 \mathrm{H}$, $\left.\mathrm{Me}_{2} \mathrm{C}_{3} H \mathrm{~N}_{2}\right), 3.41,3.30,2.91,2.55,2.50,2.48(6 \times \mathrm{s}$, $\left.36 \mathrm{H}, \mathrm{Me}_{2} \mathrm{C}_{3} \mathrm{HN}_{2}\right)$. -MS(FAB): $\mathrm{m} / \mathrm{z},(\%)=1059.2(15)$ $\left[\mathrm{M}^{+}\right] . \quad-\mathrm{C}_{36} \mathrm{H}_{48} \mathrm{~B}_{2} \mathrm{Cl}_{2} \mathrm{BrMo}_{2} \mathrm{~N}_{13} \mathrm{O}_{2} \quad$ (1059.2): calcd. C 40.82, H 4.56, N 17.19; found C 41.2, H 4.56, N 17.09. $\left[\mathrm{MoTp}^{*}(\mathrm{O}) \mathrm{Cl}\right](\mu-\mathrm{O})\left[\mathrm{MoTp} *(\mathrm{Cl})\left(\equiv \mathrm{NC}_{6} \mathrm{H}_{4} \mathrm{Br}\right)\right](\mathbf{1 b}$, trans $)$. Yield: $21 \%$. IR(KBr) $v=2548(\mathrm{~m}, \mathrm{~B}-\mathrm{H}), 956(\mathrm{~s}, \mathrm{Mo}=\mathrm{O})$, 1205 (s, Mo $\equiv \mathrm{N}), 788$ (m, Mo-O-Mo). $-{ }^{1} \mathrm{H} \mathrm{NMR}(400 \mathrm{MHz}$, $\mathrm{CDCl}_{3}$ ): $\delta=7.56\left(\mathrm{dd}, J=8 \mathrm{~Hz}, 2 \mathrm{H}, \mathrm{C}_{6} \mathrm{H}_{4} \mathrm{Br}\right.$ ), 7.47 (dd, $\left.J=8 \mathrm{~Hz}, 2 \mathrm{H}, \mathrm{C}_{6} \mathrm{H}_{4} \mathrm{Br}\right), 6.20,6.11,5.97,5.93,5.56$, $5.51\left(6 \times \mathrm{s}, 6 \mathrm{H}, \mathrm{Me}_{2} \mathrm{C}_{3} H \mathrm{~N}_{2}\right), 3.41,3.33,3.22,2.92$, $2.88, \quad 2.86\left(6 \times \mathrm{s}, \quad 36 \mathrm{H}, \quad M e_{2} \mathrm{C}_{3} \mathrm{HN}_{2}\right) . \quad-\mathrm{MS}(\mathrm{FAB}): \mathrm{m} / \mathrm{z}$ $(\%)=1059.2(20)\left[\mathrm{M}^{+}\right] .-\mathrm{C}_{36} \mathrm{H}_{48} \mathrm{~B}_{2} \mathrm{Cl}_{2} \mathrm{BrMo}_{2} \mathrm{~N}_{13} \mathrm{O}_{2}$ (1059.2): calcd. C 40.82, H 4.56, N 17.19; found C 40.8, H 4.36, N 17.47.

\section{$\left[\operatorname{MoTp}^{*}(\mathrm{O}) \mathrm{Cl}\right](\mu-\mathrm{O})\left[\mathrm{MoTp}^{*}(\mathrm{Cl})\left(\equiv \mathrm{NC}_{6} \mathrm{H}_{4} \mathrm{Cl}\right)\right](\mathbf{2})$}

A mixture of $\left[\mathrm{MoTp}^{*}(\mathrm{O}) \mathrm{Cl}_{2}\right](0.4 \mathrm{~g}, 0.83 \mathrm{mmol})$, 4-chloroaniline $(0.21 \mathrm{~g}, 1.64 \mathrm{mmol})$ and $\operatorname{dry~} \mathrm{Et}_{3} \mathrm{~N}\left(0.6 \mathrm{~cm}^{3}\right)$ in dry toluene $\left(20 \mathrm{~cm}^{3}\right)$ was heated to reflux with stirring under $\mathrm{N}_{2}$ for $16 \mathrm{~h}$. The solvent was then removed in vacuo and the crude red solid was purified by column chromatography over silica gel using $\mathrm{CH}_{2} \mathrm{Cl}_{2} / n$-hexane $(1: 1, \mathrm{v} / \mathrm{v})$ as eluant. The major red band was collected, crystallized from $\mathrm{CH}_{2} \mathrm{Cl}_{2} / n$-hexane to give microcrystals of $\left[\mathrm{MoTp}^{*}(\mathrm{O}) \mathrm{Cl}\right](\mu-\mathrm{O})\left[\mathrm{MoTp} *(\mathrm{Cl})\left(\equiv \mathrm{NC}_{6} \mathrm{H}_{4} \mathrm{Cl}\right)\right](2)$. Yield $38 \%$. IR(KBr) $v=2554$ (m, B-H), $952(\mathrm{~s}, \mathrm{Mo}=\mathrm{O}), 1208$ $(\mathrm{s}, \mathrm{Mo} \equiv \mathrm{N}), 788$ (m, Mo-O-Mo). $-{ }^{1} \mathrm{H}$ NMR (400 MHz, $\left.\mathrm{CDCl}_{3}\right): \delta=7.32\left(\mathrm{dd}, J=9 \mathrm{~Hz}, 2 \mathrm{H}, \mathrm{C}_{6} \mathrm{H}_{4} \mathrm{Cl}\right), 7.16(\mathrm{dd}$, $\left.J=9 \mathrm{~Hz}, 2 \mathrm{H}, \mathrm{C}_{6} \mathrm{H}_{4} \mathrm{Cl}\right), 5.97,5.88,5.74,5.70,5.33,5.24$ $\left(6 \times \mathrm{s}, 6 \mathrm{H}, \mathrm{Me}_{2} \mathrm{C}_{3} \mathrm{HN}_{2}\right), 2.69,2.66,2.38,2.35,2.31,2.24$ $\left(6 \times \mathrm{s}, 36 \mathrm{H}, \mathrm{Me}_{2} \mathrm{C}_{3} \mathrm{HN}_{2}\right)$. $-\mathrm{MS}(\mathrm{FAB}): \mathrm{m} / z(\%)=1014.7(10)$ $\left[\mathrm{M}^{+}\right.$]. $-\mathrm{C}_{36} \mathrm{H}_{48} \mathrm{~B}_{2} \mathrm{Cl}_{3} \mathrm{Mo}_{2} \mathrm{~N}_{13} \mathrm{O}_{2}$ (1014.7): calcd. $\mathrm{C}$ 42.61, $\mathrm{H}$ 4.76, N 17.94; found C 42.44, H 4.36, N 17.65.

\section{$X$-ray crystal structure determination}

Single crystals of $\mathbf{1 a}$ and $\mathbf{1 b}$ were coated with paraffin oil and mounted on a glass fibre. X-ray measurements were made using a Bruker SMART CCD area-detector diffractometer with Mo- $\mathrm{K}_{\alpha}$ radiation $(\lambda=0.71073 \AA$ ) [36]. Intensities were integrated [37] from several series of exposures, each exposure covering $0.3^{\circ}$ in $\omega$, and the total data set being a hemisphere. Absorption corrections were applied, based on multiple and symmetry-equivalent measurements [38]. The structure was solved by direct methods and refined by least squares on weighted $\mathrm{F}^{2}$ values for all reflections [39]. All non-hydrogen atoms were assigned anisotropic displacement parameters. Hydrogen atoms $\mathrm{H} 1 \mathrm{a}, \mathrm{H}(2 \mathrm{~A})$ were located in the 
electron density difference map, assigned isotropic displacement parameters and refined without positional constraints. All other hydrogen atoms were constrained to ideal geometries and refined with fixed isotropic displacement parameters. Complex neutral-atom scattering factors were used [40]. Crystal data for $\mathbf{1 a}$ and $\mathbf{1 b}$ and a summary of data collection and structure refinement parameters are given in Table 2.

\section{Supplementary material}

Crystallographic data for the structural analysis have been deposited with the Cambridge Crystallographic Data Centre; CCDC No. 238023 for compound 1a. $2 \mathrm{CH}_{2} \mathrm{Cl}_{2}, \mathrm{CCDC}$
No. 238032 for compound $\mathbf{1 b} \cdot 2 \mathrm{CH}_{2} \mathrm{Cl}_{2}$. Copies of this information may be obtained free of charge from The Director, CCDC, 12 Union Road, Cambridge, CB2 1EZ, UK (fax: +44-1223-336033; e-mail: deposit@ccdc.cam.ac.uk or www://www.ccdc.cam.ac.uk).

\section{Acknowledgements}

We are thankful to the Research Foundation of "Izmir Institute of Technology" and TUBITAK, Research Council of Turkey, for financial support and Prof. J. A. McCleverty for providing the $\mathrm{Tp}^{*}$ (hydrotris(3,5-dimetylpyrazolyl)borate) ligand.
[1] D. E. Wigley, Prog. Inorg. Chem. 42, 239 (1994).

[2] W. A. Nugent, J.M. Mayer, Metal-Ligand Multiple Bonds, Wiley-Interscience, New York (1988).

[3] N. Kitajima, B. W. Tolman, Prog. Inorg. Chem. 43, 419 (1995).

[4] M.S. Sanford, L.M. Henling, R.H. Grubbs, Organometallics 17, 5384 (1998).

[5] W. D. Philip, V.C. Gibson, W. Clegg, J. Chem. Soc., Dalton Trans. 3313 (1995).

[6] G. L. Casty, T. D. Tilley, G. P. A. Yap, A. L. Rheingold, Organometallics 16, 4746 (1997).

[7] V.C. Gibson, C. Redshaw, G.L.P. Walker, J.A. K. Howard, V. J. Hoy, J. M. Cole, L. G. Kuzmina, D. S. De Silva, J. Chem. Soc., Dalton Trans. 161 (1999).

[8] J.A.M. Brandts, M. V. Leur, R. A. Gossage, J. Boersma, A. L. Spek, G. V. Koten, Organometallics 18, 2633 (1999).

[9] P.J.A.M. Brandts, J. Boersma, A.L. Spek, G. Van Koten, Eur. J. Inorg. Chem. 1727 (1999).

[10] M. C. W. Chan, F. W. Lee, K. K. Cheung, C. M. Che, J. Chem. Soc., Dalton Trans. 3197 (1999).

[11] S. M. Lee, R. Kowallick, M. Marcaccio, J. A. McCleverty, M. D. Ward, J. Chem. Soc., Dalton Trans. 3443 (1998).

[12] A.S. Gamble, J. M. Boncella, Organometallics 12, 2814 (1993).

[13] J. Sundermeyer, J. Putterlink, M. Foth, J.S. Field, N. Ramesar, Chem. Ber. 127, 1201 (1994).

[14] S. Scheuer, J. Fischer, J. Kress, Organometallics 14, 2627, (1995).

[15] W. M. Vaughan, K.A. Abboub, J.M. Boncella, J. Organomet. Chem. 37, 485 (1995).

[16] J. M. Boncella, M. L. Cajigal, A. S. Gamble, K. H. Abboud, Polyhedron 15, 2071 (1996).

[17] A. Galindo, F. Montilla, A. Pastor, E. Carmona, E. Gutierrez-Puebla, A. Monge, C. Ruiz, Inorg. Chem. 36, 2379 (1997).

[18] F. Montilla, A. Pastor, A. Galindo, J. Organomet. Chem. 590, 202 (1999).
[19] A. A. Danopoulos, G. Wilkinson, B. H. Bates, M. B. Hursthouse, J. Chem. Soc., Dalton Trans. 269 (1991).

[20] A. A. Danopoulos, G. Wilkinson, T. K. N. Sweet, M. B. Hursthouse, Polyhedron 15, 873 (1996).

[21] V. Saboonchian, A. A. Danopoulos, A. Gutierrez, G. Wilkinson, D. J. Williams, Polyhedron 10, 2241 (1991).

[22] A. A. Danopoulos, G. Wilkinson, D. J. Williams, J. Chem. Soc., Chem. Commun. 181 (1991).

[23] H. W. Lam, G. Wilkinson, D. J. Williams, Polyhedron 10, 2647 (1991).

[24] V.C. Gibson, C. Redshaw, G. L.P. Walker, W. Clegg, M. R. J. Elsegood, J. Organomet. Chem. 689, 332 (2004).

[25] J. B. Strong, B.S. Haggerty, A. L. Rheinhold, E. A. Maatta, Chem. Commun. 1137 (1997).

[26] V. C. Gibson, A. J. Graham, D. L. Ormsby, B. P. Ward, A. J.P. White, D. J. Williams, J. Chem. Soc., Dalton Trans. 2597 (2002).

[27] K. Dehnicke, J. Strähle, Angew. Chem., Int. Ed. Engl. 20, 413 (1981).

[28] A. Miller, C. Doonan, L. Laughlin, E. R. T. Tiekink, C. Young, Inorg. Chim. Acta 337, 393 (2002).

[29] S. Lincoln, S. A. Koch, Inorg. Chem. 25, 1594 (1986).

[30] S. Lincoln, T. M. Loehr, Inorg. Chem. 29, 1907 (1990).

[31] P. Barrie, T. A. Coffey, G. D. Forster, G. Hogarth, J. Chem. Soc., Dalton Trans. 4519 (1999).

[32] K. A. Rufanov, D. N. Zarubin, N. A. Ustynyuk, D. N. Gourecitch, J. Sundermeyer, A. V. Churakov, J. A. K. Howard, Polyhedron 20, 379 (2001).

[33] A. G. Orpen, L. Brammer, F. H. Allen, O. Kennard, D. G. Watson, R. Taylor, J. Chem. Soc., Dalton Trans. S1 (1989).

[34] C. D. Garner, J. M. Charnock, in: G. Wilkinson, R. D. Gillard, J. A. McCleverty (Eds), Comprehensive Coordination Chemistry, p. 1329, Pergamon, Oxford (1987).

[35] S. A. Roberts, C. G. Young, C. A. Kippe, J. W. E. Cleland, K. Yamanouchi, M. D. Carducci, J. H. Enemark, Inorg. Chem. 29, 3650 (1990). 
[36] W. L. Madison, SMART Diffractometer Control Software, Bruker Analytical X-ray Instruments Inc. (1998).

[37] W. L. Madison, SAINT integration software, Siemens Analytical X-ray Instruments Inc. (1994).

[38] G. M. Sheldrick, SADABS: A program for absorption correction with the Siemens SMART system (1996).
[39] W.L. Madison, SHELXTL program system version 5.1; Bruker Analytical X-ray Instruments Inc. (1998).

[40] International Tables for Crystallography, Kluwer, Dordrecht (1992). 